\title{
Two Way Fixed EFFECT OF Priority SECTOR LENDING (SECTOR WiSE) ON NON PERFORMING ASSETS OF INDIAN COMMERCIAL BANKS
}

\author{
Neha Goyal, Dr Rachna Agrawal and Dr.Renu Aggarwal \\ Asst, Professor YMCA UST Faridabad \\ Associate Professor YMCA UST Faridabad \\ YMCA UST Faridabad
}

\begin{abstract}
:
Reserve Bank of India has fixed some targets and sub targets for all commercial banks for PSL (Priority Sector Lending). Priority sector lending refers to that sector of economy which is not getting adequate financial assistance from different financial institutions. Due to Priority sector Lending, Non-performing assets of the banks are increasing day by day. This research paper is an attempt to measure the two way effect of every sector of PSL on NPA for public and private banks. Effect between PSL and NPA is found with the help of E Views Software. The period of study is 2001 to 2013. For the analysis Pooled Regression Model, Panel Regression Model and Two Way Fixed Effect Model is used.
\end{abstract}

\section{KEYWORDS:}

Priority Sector Lending, Non Performing Assets, Agriculture PSL, SSI PSL, Other PSL, Private Banks and Public Banks.

\section{INTRODUCTION:}

Non-performing Assets is the biggest matter of concern for any banking institution. It affects the profitability of any bank. In India the concept of NPA came into existence after the financial sector reforms were introduced following the recommendations of the Report of the Committee on the Financial System (Narasimham, 1991). Broadly, Non Performing Advance is defined as an advance where payment of interest or repayment of instalment of principal (in case of term loans) or both remains unpaid for a certain period. In India, the definition of NPAs has changed over time. According to the Narasimham (1991) committee report, those assets (advances, bills discounted, overdrafts, cash credit etc) for which the interest remain due for a period of four quarters (180 days) should be considered as NPAs. Subsequently this period was reduced, and from March 1995 onwards the assets for which the interest has remained unpaid for 90 days should be considered as NPAs. Accordingly, with effect from March 31, 2004 a Non Performing Asset (NPA) should be a loan or an advance where;

a) Interest and/or installment of principal remains overdue for a period of more than 90 days in respect of a term loan

b) The account remains 'out of order' for a period of more than 90 days, in respect of an over Draft / Cash Credit.

c) The bill remains overdue for a period of more than 90 days in case of bills purchased and discounted 
d) Interest and/or installment of principal remains overdue for two harvest seasons but for a period not exceeding two and a half years in the case of an advance granted for agricultural purpose

e) Any amount to be received remains overdue for a period of more than 90 days in respect of other accounts.

Priority sector lending refers to that sector of economy which is not getting adequate financial assistance from different financial institutions. The main motive is to achieve socio economic equality. Priority Sector Lending includes Agriculture, Small Scale Industries and Weaker Sections etc. The targets under PSL have been fixed by RBI for different types of banks.

\subsection{TARGETS}

As per extant instructions, the targets and sub-targets set under priority sector lending for domestic and foreign banks operating in India are given below:

\begin{tabular}{|l|l|l|}
\hline \multicolumn{2}{|c|}{ Table 1: Targets for Domestic Commercial Banks } \\
\hline $\begin{array}{l}\text { Total Priority } \\
\text { Sector } \\
\text { advances }\end{array}$ & $\begin{array}{l}\text { 40 per cent of Adjusted Net Bank } \\
\text { Credit (ANBC) }\end{array}$ & Same \\
\hline $\begin{array}{l}\text { Agriculture } \\
\text { Advances }\end{array}$ & $\begin{array}{l}\text { 18 per cent of ANBC out of which } \\
\text { indirect agriculture. }\end{array}$ \\
\hline $\begin{array}{l}\text { Micro \& Small } \\
\text { Enterprise } \\
\text { advances } \\
\text { (MSE) }\end{array}$ & No Target & $\begin{array}{l}18 \% \text { of ANBC } \\
\text { fixed ANBC for small } \\
\text { and marginal } \\
\text { farmers) } \\
\text { No direct and } \\
\text { indirect } \\
\text { agriculture }\end{array}$ \\
\hline Export Credit & No Target & $\begin{array}{l}7.5 \% \text { of ANBC } \\
\text { is fixed for micro } \\
\text { enterprises }\end{array}$ \\
\hline $\begin{array}{l}\text { Advances to } \\
\text { Weaker Section }\end{array}$ & 10 per cent of ANBC & $\begin{array}{l}12 \text { per cent of } \\
\text { ANBC }\end{array}$ \\
\hline
\end{tabular}

$\begin{array}{lcccc}\text { Source: } & \text { Master Circular RBI/July/2012-13/108 and } \quad \text { RBI/2014-15/573 } \\ \text { FIDD.CO.Plan.BC.54/04.09.01/2014-15 }\end{array}$

It is clear from Table 1 that because of fixation of targets by RBI, commercial banks must lend to Priority Sector. The present study is an attempt to find out the impact of PSL on NPA. The study is classified in to 9 sections. Section 1 gives the brief introduction of PSL and NPA. Section 2 review the past studies related to NPA and PSL and find the research gap. Section 3 is about the research methodology, which tells about the objectives of the study, data collection method and 
steps followed to achieve the objectives. Section 4 is data analysis which comprise of 4 sub sections. Section 4.1 shows the impact of PSL on NPA. Section 4.2 shows the impact of Agriculture PSL on NPA. Section 4.3 shows the impact of SSI PSL on NPA. Section 4.4 shows the impact of Other PSL on NPA. Section 5 is findings. Section 6 concludes the study. Section 7 is of abbreviation. Section 8 is of list of tables. Section 9 is references.

\section{LITERATURE REVIEW:}

The concept of Priority Sector Lending is formalized in 1972, in year 1979 all banks were advised to give one third of their advances to priority sectors. In 1980 RBI working group under Dr. K. S. Krishaswamy suggested to extend the PSL target from 33\% to 40\%. In 1991 Narshimam Committee suggested to phase out the concept of PSL as it is increasing the NPA burden of banks. The recommendation of the committee was not accepted. In 1998 Narshimam Committee again give the report and admitted that PSL is very necessary. In 1995 RIDF fund had been established, and banks are directed to submit the gap amount of PSL target in RIDF. Since then several changes had been made in PSL targets and sub targets and various studies has been done.

Ghosh, 2011 in his study found that Priority sectors like agriculture, SSI and others are also a reason of increasing NPA of Public and Private sector banks.

Reddy K Prashnath, 2002 in his study done the comparative analysis of Indian banks and -foreign banks, Author found that main reason of NPA of Indian commercial banks is legal impositions, like fixation of priority sector target.

Selvam N, 2013, done a study on customer perception regarding NPA of commercial banks, author found that customer also feel that social and political pressure in form of PSL also play a major role in increasing NPA.

Laveena, Malhotra Meenakshi, 2014 done a study on NPA and PSL. Researcher has analysed the NPA and PSL from 2002 to 2014. He has analysed the data by various statistical tools like ration correlation and regression. According to his study the coefficient of determination is 0.887 ; therefore, about $88.7 \%$ of the variation in the gross NPA data is explained by priority sector lending.

Patidar Suresh and Kataria Ashwini 2012 has conducted study to analyze priority sector lending by selected public and private sector banks in India. Researchers assessed based on using statistical tools like regression analysis, ratio analysis and t-test. The authors found the significant impact of priority sector lending on total NPA of Public Sector banks, whereas in case of Private Sector Banks, there was no significant impact of priority sector lending on total NPA of Banks. Also the result showed the significant difference between NPA of SBI \& Associates, Old Private Banks and New Private Banks with the NPA of Nationalized Banks, the benchmark category.

Shabbir Najmi, Mujoo Rachna,2013 has conducted a study for the comparison of NPA between private and public banks. Researchers found that NPA of public banks as compare to private sector banks is high because PSL of public banks is high than private banks.

Dr. G Nagarajan., N. Sathyanarayana, Ali Asif, 2013 studied the relationship between recovery and NPA. Researchers found that the main reason of NPA is writing off bad loans and bad loans are more in case of PSL in comparison of non PSL. 
The above studies find that there is relation between NPA and PSL. PSL is a leading factor of NPA. PSL is divided into many sectors like Agriculture, SSI and others but according to the above mentioned studies and to the best knowledge of researcher, this is still to be studied that which sector of PSL is responsible for NPA and up to what extent. This study is an attempt to find out that, among various sectors of PSL, what is the role of each sector to increase NPA.

\section{RESEARCH DESIGN AND METHODOLOGY:}

The data analyzed in the study is Panel data. Panel data is a data that involves measurements of many individual units over a period of time. In the study the PSL impact of public banks and private banks is studied over NPA for 13 years.

\subsection{Sampling:}

For the purpose of analyzing impact of PSL on NPA, the whole population of Public Sector and Private Sector has been considered. PSL has been classified in 3 sectors.

1. Agriculture

2. SSI

3. Others

The data has been collected from the RBI website for the period of 13 years i.e. 2001 to 2013. Secondary data has been used in this research.

\subsection{Objectives:}

The main objectives of the study are:

1. To find out two way fixed effect of Priority Sector Lending on Total NPA of public and private banks

2. To find out two way fixed effect of Priority Sector Lending on Total NPA

2.1. To find out the two way fixed effect of Agriculture Priority Sector Lending on Total NPA

2.2. To find out the two way fixed effect of SSI Priority Sector Lending on Total NPA

2.3. To find out the two way fixed effect of Other Priority Sector Lending on Total NPA

For every objective the following models have been used:

a. Pooled Regression Model: Firstly the relationship is found with the help of pooled regression model. Pooled Regression Model tells the pooled effect of PSL on NPA of both public and private sector banks.

b. Panel regression model: After applying the pooled regression model the panel regression model is applied to know whether the fixed intercept of public and private banks is same or not. For this, F test (Fixed effect) and Hausman test (Random effect) is applied.

c. Two way fixed effect model: Panel regression model has given different intercepts for public banks and private banks. so after applying the panel regression model the two way fixed effect model is applied to know whether the sensitivity coefficient $(\beta)$ is also different or not. 


\section{Data Analysis:}

Table 2 present the NPA and PSL of public and private sector banks from 2000 to 2013. Colum 2 is total NPA of public sector bank from 2000 to 2013. Colum 6 is PSL of public sector banks. Priority sector is further categorized in to three categories, Agriculture, SSI and others. Colum 3 is agriculture Priority Sector Lending of public sector banks. Colum 4 is SSI Priority Sector Lending of public sector banks. Colum 5 is Other Priority Sector Lending of public sector banks. Similarly Colum 7 is total NPA of private sector bank from 2000 to 2013. Colum 11 is PSL of private sector banks. Colum 8 is agriculture Priority Sector Lending of private sector banks. Colum 9 is SSI Priority Sector Lending of private sector banks. Colum 10 is Other Priority Sector Lending of private sector banks.

\begin{tabular}{|l|l|l|l|l|l|l|l|l|l|l|}
\hline \multicolumn{2}{|c|}{ Table 2: Total NPA and PSL of Public and Private Banks } \\
(amount in Rs. Crore)
\end{tabular}

*Source: Report of Trend and Progress of Banking in India, Reserve Bank of India (from 2000 to 2013)

\subsection{Impact of PSL on NPA:}

In the study the effort is done in order to analyse the impact of Priority Sector Lending of public and private banks on their total net performance basis. The pooled regression model is applied considering NPA as dependent variable and PSL as independent variable. The pooled regression model can be mathematically expressed as:

$N P A=\alpha+\beta \cdot P S L+E$ 
The result of pooled regression model is shown below in table 3:

\begin{tabular}{|c|c|c|c|c|c|}
\hline $\begin{array}{l}\text { Dependent } \\
\text { Variable }\end{array}$ & $\begin{array}{l}\text { Independent } \\
\text { Variable }\end{array}$ & $\begin{array}{l}\text { Regression } \\
\text { Coefficients }\end{array}$ & t-stat. (p-value) & $\mathrm{R}^{2}$ & $\begin{array}{l}\text { F stat. } \\
\text { (p value) }\end{array}$ \\
\hline \multirow[t]{2}{*}{ Total NPA } & Intercept & 7976.258 & $\begin{array}{l}1.489 \\
(.149)\end{array}$ & \multirow[t]{2}{*}{$71.96 \%$} & \multirow[t]{2}{*}{$60.795(.000)$} \\
\hline & PSL & 0.082 & $\begin{array}{l}7.797 \\
(.000)\end{array}$ & & \\
\hline
\end{tabular}

The result indicates the $\mathrm{p}$ value of $\mathrm{t}$ statistics (7.000) is found to be less than $5 \%$ level of significance hence with $95 \%$ confidence level the null hypothesis of no significant impact of PSL on NPA cannot be accepted. Thus it can be concluded that PSL of banks have significant impact on the NPA of banks. The regression equation can be written as:

$\mathrm{NPA}=7976.258+0.082 \mathrm{PSL}$

The regression model indicates that slope coefficient of PSL is found to be 0.082 which is positive and found significant. Hence it can be concluded that there exist significant positive impact of PSL on NPA. The result of regression model indicates that if banks offer 1 rupee of PSL there NPA increase by 8.2 paise. The F statistics of the regression model is found to be 60.79 with $p$ value of (.000) which indicates that the pooled regression model is statistically fit. The $\mathrm{R}^{2}$ is $71.96 \%$ which indicates that approximately $72 \%$ of variance in the behaviour of NPA can be explained with the help of regression model.

\subsubsection{Panel Regression Model of NPA and PSL:}

After applying the pooled regression model the panel regression model is applied to decide fixed effect versus random effect model. The F test as well as Hausman test is applied. The F test indicates that whether fixed effect is significant or not. If $\mathrm{p}$ value of $\mathrm{F}$ Statistics is found to be less than 5\% level of significance it indicates that the presence of size effect of banks of banks in analysing the impact of PSL on NPA. In other words fixed effect model is better than pooled regression model, similarly Hausman test is used to test whether the effects are random or not. Hausman statistics test the null hypothesis that the effects are random. If $\mathrm{P}$ value of Hausman test is found to be more than $5 \%$ level of significance random effect model is applied.

The result of $F$ test and Hausman test shown below:

\begin{tabular}{|l|l|l|}
\hline \multicolumn{3}{|l|}{ Table 4: Panel Regression Model of Total NPA and PSL } \\
\hline & F test & Hausman test \\
\hline & F test (p value) & Cross Section random (p value) \\
\hline Cross Section Effect & $7.020(0.014)$ & $7.020(0.008)$ \\
\hline Time effect & $1.33(.312)$ & $5.03(0.024)$ \\
\hline
\end{tabular}

The results as shown above in table 4 indicate that the $\mathrm{P}$ value of $\mathrm{F}$ statistics is significant (less than 5 percent level of significance) hence fixed effect model is statistically better than Pooled Regression model. The Hausman test indicates that the effects are not random since the $\mathrm{P}$ value of Hausman test is found to be less than 5\% level of significance. In other words it can be concluded that the impact of PSL on NPA in case of public and private banks are different. 


\subsubsection{Two Way Fixed Effect Panel Regression of Total NPA and PSL:}

In previous regression fixed effect model, it was assumed that intercept is different for public and private banks in analyzing the impact of PSL on NPA. It may be possible not only intercept but also sensitivity of NPA to PSL is also different for public and private banks. The following fixed effect model where intercept as well as slope coefficient for both public and private banks may be different is applied.

$N P A=\alpha+\beta_{1}$ Dprivate $+\beta 2$ PSL $+\beta 3$ Dprivate. PSL

The results of fixed effect using equation are shown below in table 5:

\begin{tabular}{|l|l|l|l|l|l|}
\hline \multicolumn{6}{|l|}{ Table 5: Two Way Fixed Effect Panel Regression Model of Total NPA and PSL } \\
\hline $\begin{array}{l}\text { Dependent } \\
\text { Variable }\end{array}$ & $\begin{array}{l}\text { Independent } \\
\text { Variable }\end{array}$ & $\begin{array}{l}\text { Regression } \\
\text { Coefficients }\end{array}$ & t-stat. (p-value) & R $^{2}$ & $\begin{array}{l}\text { F stat. } \\
\text { (p value) }\end{array}$ \\
\hline \multirow{4}{*}{ NPA } & Intercept & 27710.06 & $2.89(0.008)$ & 78.5 & $26.89(.000)$ \\
\cline { 2 - 5 } & Dummy Private & -18152.12 & $-1.48(0.152)$ & 5 & \\
\cline { 2 - 5 } & PSL & 0.0636 & $4.987(.000)$ & & \\
\cline { 2 - 5 } & Dpr*PSL & -0.025 & $-0.518(.609)$ & & \\
\hline
\end{tabular}

The results indicate that $\alpha$ is found to be positive. In this regression model as public sector banks are assumed to be reference hence the NPA in case of no PSL is positive. In addition to this the slope coefficient of dummy private is found to be negative, which indicates low level of NPA in case of private banks as compare to public banks. The slope coefficient is $(0.0636)$ represents the impact of PSL on NPA in case of public sector banks, which represents that increase in the PSL of 100 Rs would lead to 6.36 Rs increase in NPA. However the slope coefficient of interaction dummy (dummy of private* PSL) is found to be -0.025 which represents that in case of private banks the net increase of NPA is Rs. 2.5 less than as result of 100 Rs. increase in PSL as compare to public sector banks. In absolute terms in case of private banks as a result of 100 Rs. increases in PSL the net increase in NPA is equal to (6.36-2.56) 3.8. Finally it can be concluded that private sector banks are more efficient in managing NPA in relation with PSL.

\subsection{Impact of Agriculture PSL Lending on NPA:}

In the study the effort is done in order to analyse the impact of Agriculture Priority Sector Lending of public and private banks on their total net performance basis. The pooled regression model is applied considering NPA as dependent variable and Agriculture PSL as independent variable. The pooled regression model can be mathematically expressed as:

\section{$N P A=\alpha+\beta \cdot A g r i P S L+E$}

The result of pooled regression model is shown below in table 6 :

\begin{tabular}{|l|l|l|l|l|l|}
\hline \multicolumn{6}{|l|}{ Table 6: Pooled Regression between Total NPA and Agriculture PSL } \\
\hline $\begin{array}{l}\text { Dependent } \\
\text { Variable }\end{array}$ & $\begin{array}{l}\text { Independent } \\
\text { Variable }\end{array}$ & $\begin{array}{l}\text { Regression } \\
\text { Coefficients }\end{array}$ & $\begin{array}{l}\text {-stat. } \\
\text { value) }\end{array}$ & $\begin{array}{l}\text { F stat. } \\
\text { (p value })\end{array}$ \\
\hline Total NPA & Intercept & 10038.69 & $\begin{array}{l}1.920 \\
(.066)\end{array}$ & $71.14 \%$ & $59.179(.000)$ \\
& Agri PSL & 0.193 & $\begin{array}{l}7.692 \\
(.000)\end{array}$ & & \\
\cline { 2 - 5 } & & & & \\
\hline
\end{tabular}


The result indicates the $\mathrm{p}$ value of $\mathrm{t}$ statistics (7.000) is found to be less than $5 \%$ level of significance hence with $95 \%$ confidence level the null hypothesis of no significant impact of Agriculture PSL on NPA cannot be accepted. Thus it can be concluded that Agriculture PSL of banks has significant impact on the NPA of banks. The regression equation can be written as:

NPA $=10038.69+0.193$ Agri PSL

The regression model indicates that slope coefficient of Agriculture PSL is found to be 0.193 which is positive and found significant. Hence it can be concluded that there exist significant positive impact of Agriculture PSL on NPA. The result of regression model indicates that if banks offer 1 rupee of Agriculture PSL there NPA increase by 19.3 paise. The F statistics of the regression model is found to be 59.179 with $\mathrm{p}$ value of (.000) which indicates that the pooled regression model is statistically fit. The $\mathrm{R}^{2}$ is $71.14 \%$ which indicates that approximately $71 \%$ of variance in the behaviour of NPA can be explained with the help of regression model.

\subsubsection{Panel Regression Model of Total NPA and Agriculture PSL:}

After applying the pooled regression model the panel regression model is applied to decide fixed effect versus random effect model. The result of $\mathrm{F}$ test and Hausman test shown below:

\begin{tabular}{|l|l|l|}
\hline \multicolumn{2}{|c|}{ Table 7: Panel Regression between Total NPA and Agriculture PSL } \\
\hline & F test & Hausman test \\
\hline & F test (p value) & Cross Section random (p value) \\
\hline Cross Section Effect & $7.577(0.011)$ & $7.577(0.005)$ \\
\hline Time effect & $1.323(0.317)$ & $4.679(0.030)$ \\
\hline
\end{tabular}

The results as shown above in table indicate that the $\mathrm{P}$ value of $\mathrm{F}$ statistics is significant (less than 5 percent level of significance) hence fixed effect model is statistically better than Pooled Regression model. The Hausman test indicates that the effects are not random since the $\mathrm{P}$ value of Hausman test is found to be less than 5\% level of significance. In other words it can be concluded that the impact of Agriculture PSL on NPA in case of public and private banks are different.

\subsubsection{Two Way Fixed Effect Panel Regression of Total NPA and Agriculture PSL:}

In previous regression fixed effect model, it was assumed that intercept is different for public and private banks in analyzing the impact of Agriculture PSL on NPA. It may be possible not only intercept but also sensitivity of NPA to Agriculture PSL is also different for public and private banks. The following fixed effect model where intercept as well as slope coefficient for both public and private banks may be different is applied.

$N P A=\alpha+\beta_{1}$ Dprivate $+\beta 2$ Agri PSL $+\beta 3$ Dprivate.Agri PSL 
The results of fixed effect using equation are shown below in table 8:

\begin{tabular}{|c|c|c|c|c|c|}
\hline $\begin{array}{l}\text { Dependent } \\
\text { Variable }\end{array}$ & $\begin{array}{l}\text { Independent } \\
\text { Variable }\end{array}$ & $\begin{array}{l}\text { Regression } \\
\text { Coefficients }\end{array}$ & t-stat. (p-value) & $\mathrm{R}^{2}$ & $\begin{array}{l}\text { F stat. } \\
\text { (p value) }\end{array}$ \\
\hline \multirow[t]{4}{*}{ NPA } & Intercept & 28177.46 & $3.30(0.003)$ & \multirow[t]{4}{*}{78.4} & \multirow[t]{4}{*}{$26.63(.000)$} \\
\hline & Dummy Private & -20314.47 & $-1.72(0.097)$ & & \\
\hline & Agri PSL & 0.1471 & $4.948(.000)$ & & \\
\hline & Dpr*Agri PSL & -0.0447 & $-0.341(.735)$ & & \\
\hline
\end{tabular}

The results indicate that $\alpha$ is found to be positive. In this regression model as public sector banks are assumed to be reference hence the NPA in case of no Agriculture PSL is positive. In addition to this the slope coefficient of dummy private is found to be negative, which indicates low level of NPA in case of private banks as compare to public banks. The slope coefficient is $(0.1471)$ represents the impact of Agriculture PSL on NPA in case of public sector banks, which represents that increase in the Agriculture PSL of 100 Rs would lead to 14.71 Rs increase in NPA. However the slope coefficient of interaction dummy (dummy of private* Agriculture PSL) is found to be 0.0447 which represents that in case of private banks the net increase of NPA is Rs. 4.47 less than as result of 100 Rs. increase in Agriculture PSL as compare to public sector banks. In absolute terms in case of private banks as a result of 100 Rs. increases in Agriculture PSL the net increase in NPA is equal to (14.71-4.47) 10.24 Finally it can be concluded that private sector banks are more efficient in managing NPA in relation with Agriculture PSL.

\subsection{Impact of SSI PSL Lending on NPA:}

In the study the effort is done in order to analyse the impact of SSI Priority Sector Lending of public and private banks on their total net performance basis. The pooled regression model is applied considering NPA as dependent variable and SSI PSL as independent variable. The pooled regression model can be mathematically expressed as:

$N P A=\alpha+\beta . S S I P S L+E$

The result of pooled regression model is shown below in table 9:

\begin{tabular}{|l|l|l|l|l|l|}
\hline \multicolumn{7}{|l|}{ Table 9: Pooled Regression between Total NPA and SSI PSL } \\
\hline $\begin{array}{l}\text { Dependent } \\
\text { Variable }\end{array}$ & $\begin{array}{l}\text { Independent } \\
\text { Variable }\end{array}$ & $\begin{array}{l}\text { Regression } \\
\text { Coefficients }\end{array}$ & $\begin{array}{l}\text { t-stat. } \\
\text { value) }\end{array}$ & $\mathrm{R}^{2}$ & $\begin{array}{l}\text { F stat. } \\
\text { (p value) }\end{array}$ \\
\hline \multirow{2}{*}{ NPA } & Intercept & 12551.92 & $\begin{array}{l}2.636 \\
(0.014)\end{array}$ & $\begin{array}{l}73.52 \\
\%\end{array}$ & $66.638(.000)$ \\
& & & $8.163(.000)$ & \\
\cline { 2 - 5 } & SSI PSL & 0.229 & & \\
\hline
\end{tabular}

The result indicates the $\mathrm{p}$ value of $\mathrm{t}$ statistics (7.000) is found to be less than $5 \%$ level of significance hence with $95 \%$ confidence level the null hypothesis of no significant impact of SSI PSL on NPA cannot be accepted. Thus it can be concluded that SSI PSL of banks has significant impact on the NPA of banks. The regression equation can be written as:

$$
\mathrm{NPA}=12551.92+0.229 \text { SSI PSL }
$$


The regression model indicates that slope coefficient of SSI PSL is found to be 0.229 which is positive and found significant. Hence it can be concluded that there exist significant positive impact of SSI PSL on NPA. The result of regression model indicates that if banks offer 1 rupee of SSI PSL there NPA increase by 22.9 paise. The F statistics of the regression model is found to be 66.638 with $\mathrm{p}$ value of (.000) which indicates that the pooled regression model is statistically fit. The $\mathrm{R}^{2}$ is $73.52 \%$ which indicates that approximately $73 \%$ of variance in the behaviour of NPA can be explained with the help of regression model.

\subsubsection{Panel Regression Model of Total NPA and SSI PSL:}

After applying the pooled regression model the panel regression model is applied to decide fixed effect versus random effect model. The result of $F$ test and Hausman test shown below in table 10:

\begin{tabular}{|l|l|l|}
\hline \multicolumn{3}{|c|}{ Table 10: Panel Regression between Total NPA and SSI PSL } \\
\hline & F test & Hausman test \\
\hline & F test (p value) & Cross Section random (p value) \\
\hline Cross Section Effect & $15.402(0.000)$ & $15.402(0.000)$ \\
\hline Time effect & $1.171(0.394)$ & $7.446(0.006)$ \\
\hline
\end{tabular}

The results as shown above in table indicate that the $\mathrm{P}$ value of $\mathrm{F}$ statistics is significant (less than 5 percent level of significance) hence fixed effect model is statistically better than Pooled Regression model. The Hausman test indicates that the effects are not random since the $\mathrm{P}$ value of Hausman test is found to be less than 5\% level of significance. In other words it can be concluded that the impact of SSI PSL on NPA in case of public and private banks are different.

\subsubsection{Two Way Fixed Effect Panel Regression of Total NPA and SSI PSL:}

In previous regression fixed effect model, it was assumed that intercept is different for public and private banks in analyzing the impact of SSI PSL on NPA. It may be possible not only intercept but also sensitivity of NPA to SSI PSL is also different for public and private banks. The following fixed effect model where intercept as well as slope coefficient for both public and private banks may be different is applied.

\section{NPA $=\alpha+\beta_{1}$ Dprivate $+\beta 2$ SSI PSL $+\beta 3$ Dprivate.SSI PSL}

The results of fixed effect using equation are shown below in table 11:

\begin{tabular}{|l|l|l|l|l|l|}
\hline \multicolumn{5}{|l|}{ Table 11: Two Way Fixed Effect Panel Regression between Total NPA and SSI PSL } \\
\hline $\begin{array}{l}\text { Dependent } \\
\text { Variable }\end{array}$ & $\begin{array}{l}\text { Independent } \\
\text { Variable }\end{array}$ & $\begin{array}{l}\text { Regression } \\
\text { Coefficients }\end{array}$ & $\begin{array}{l}\text { t-stat. } \\
\text { (p-value) }\end{array}$ & $\mathrm{R}^{2}$ & $\begin{array}{l}\text { F stat. } \\
\text { (p value) }\end{array}$ \\
\hline \multirow{4}{*}{ NPA } & Intercept & 30466.05 & $4.79(0.000)$ & \multirow{2}{*}{84.7} & $40.893(0.000)$ \\
\cline { 2 - 4 } & Dummy Private & -21259.86 & $-2.5(0.020)$ & & \\
\cline { 2 - 4 } & SSI PSL & 0.182 & $6.63(.000)$ & & \\
\cline { 2 - 4 } & Dpr*SSI PSL & -0.0930 & $-0.97(.341)$ & & \\
\hline
\end{tabular}

The results indicate that $\alpha$ is found to be positive. In this regression model as public sector banks are assumed to be reference hence the NPA in case of no SSI PSL is positive. In addition to this the slope coefficient of dummy private is found to be negative, which indicates low level of NPA in case of private banks as compare to public banks. The slope coefficient is $(0.182)$ represents 
the impact of SSI PSL on NPA in case of public sector banks, which represents that increase in the SSI PSL of 100 Rs would lead to 18.2 Rs increase in NPA. However the slope coefficient of interaction dummy (dummy of private* SSI PSL) is found to be -0.093 which represents that in case of private banks the net increase of NPA is Rs. 9.3 less than as result of 100 Rs. increase in SSI PSL as compare to public sector banks. In absolute terms in case of private banks as a result of 100 Rs. increases in SSI PSL the net increase in NPA is equal to (18.2-9.3) 8.9 Finally it can be concluded that private sector banks are more efficient in managing NPA in relation with SSI PSL.

\subsection{Impact of Other PSL Lending on NPA:}

In the study the effort is done in order to analyse the impact of Other Priority Sector Lending of public and private banks on their total net performance basis. The pooled regression model is applied considering NPA as dependent variable and Other PSL as independent variable. The pooled regression model can be mathematically expressed as:

$N P A=\alpha+\beta$. Other PSL $+E$

The result of pooled regression model is shown below in table 12:

\begin{tabular}{|l|l|l|l|l|l|}
\hline \multicolumn{6}{|l|}{ Table 12: Pooled Regression between Total NPA and Other PSL } \\
\hline $\begin{array}{l}\text { Dependent } \\
\text { Variable }\end{array}$ & $\begin{array}{l}\text { Independent } \\
\text { Variable }\end{array}$ & $\begin{array}{l}\text { Regression } \\
\text { Coefficients }\end{array}$ & $\begin{array}{l}\text { t-stat. (p- } \\
\text { value) }\end{array}$ & $\begin{array}{l}\text { R stat. } \\
\text { (p value) }\end{array}$ \\
\hline \multirow{2}{*}{ NPA } & Intercept & 3902.663 & $0.515(.610)$ & $57.19 \%$ & $32.066(.000)$ \\
\cline { 2 - 6 } & Other PSL & 0.310 & $\begin{array}{l}5.662 \\
(0.000)\end{array}$ & & \\
\hline
\end{tabular}

The result indicates the $\mathrm{p}$ value of $\mathrm{t}$ statistics (7.000) is found to be less than $5 \%$ level of significance hence with $95 \%$ confidence level the null hypothesis of no significant impact of Other PSL on NPA cannot be accepted. Thus it can be concluded that Other PSL of banks has significant impact on the NPA of banks. The regression equation can be written as:

$\mathrm{NPA}=3902.663+0.310$ Other PSL

The regression model indicates that slope coefficient of Other PSL is found to be 0.310 which is positive and found significant. Hence it can be concluded that there exist significant positive impact of Other PSL on NPA. The result of regression model indicates that if banks offer 1 rupee of Other PSL there NPA increase by 31 paise. The F statistics of the regression model is found to be 32.066 with $\mathrm{p}$ value of (.000) which indicates that the pooled regression model is statistically fit. The $\mathrm{R}^{2}$ is $57.19 \%$ which indicates that approximately $57 \%$ of variance in the behaviour of NPA can be explained with the help of regression model.

\subsubsection{Panel Regression Model of Total NPA and Other PSL:}

After applying the pooled regression model the panel regression model is applied to decide fixed effect versus random effect model. The result of $F$ test and Hausman test shown below in table 13:

\begin{tabular}{|l|l|l|}
\hline \multicolumn{3}{|c|}{ Table 13: Panel Regression between Total NPA and Other PSL } \\
\hline & F test & Hausman test \\
\hline & F test (p value) & Cross Section random (p value) \\
\hline Cross Section Effect & $4.381(0.047)$ & $4.381(0.036)$ \\
\hline Time effect & $1.671(0.192)$ & $3.640(0.056)$ \\
\hline
\end{tabular}


The results as shown above in table indicate that the $\mathrm{P}$ value of $\mathrm{F}$ statistics is significant (less than 5 percent level of significance) hence fixed effect model is statistically better than Pooled Regression model. The Hausman test indicates that the effects are not random since the $\mathrm{P}$ value of Hausman test is found to be less than 5\% level of significance. In other words it can be concluded that the impact of Other PSL on NPA in case of public and private banks are different.

\subsubsection{Two Way Fixed Effect Panel Regression of Total NPA and Other PSL:}

In previous regression fixed effect model, it was assumed that intercept is different for public and private banks in analyzing the impact of Other PSL on NPA. It may be possible not only intercept but also sensitivity of NPA to Other PSL is also different for public and private banks. The following fixed effect model where intercept as well as slope coefficient for both public and private banks may be different is applied.

\section{NPA $=\alpha+\beta_{1}$ Dprivate $+\beta 2$ Oter PSL $+\beta 3$ Dprivate.Oter PSL}

The results of fixed effect using equation are shown below in table:

\begin{tabular}{|l|l|l|l|l|l|}
\hline \multicolumn{6}{|l|}{ Table 14: Two Way Fixed Effect Panel Regression between Total NPA and Other PSL } \\
\hline $\begin{array}{l}\text { Dependent } \\
\text { Variable }\end{array}$ & $\begin{array}{l}\text { Independent } \\
\text { Variable }\end{array}$ & $\begin{array}{l}\text { Regression } \\
\text { Coefficients }\end{array}$ & $\begin{array}{l}\text { t-stat. } \\
\text { (p-value) }\end{array}$ & $\mathrm{R}^{2}$ & $\begin{array}{l}\text { F stat. } \\
\text { (p value) }\end{array}$ \\
\hline \multirow{4}{*}{ NPA } & Intercept & 28216.33 & $1.85(0.076)$ & 64.29 & $13.204(0.000)$ \\
\cline { 2 - 4 } & Dummy Private & -20093.44 & $-0.98(0.337)$ & & \\
\cline { 2 - 4 } & Other PSL & 0.203 & $2.517(.019)$ & & \\
\cline { 2 - 4 } & Dpr*Other PSL & -0.103 & $-0.39(.698)$ & & \\
\hline
\end{tabular}

The results indicate that $\alpha$ is found to be positive. In this regression model as public sector banks are assumed to be reference hence the NPA in case of no Other PSL is positive. In addition to this the slope coefficient of dummy private is found to be negative, which indicates low level of NPA in case of private banks as compare to public banks. The slope coefficient is (0.203) represents the impact of Other PSL on NPA in case of public sector banks, which represents that increase in the Other PSL of 100 Rs would lead to 20.3 Rs increase in NPA. However the slope coefficient of interaction dummy (dummy of private* Other PSL) is found to be -0.103 which represents that in case of private banks the net increase of NPA is Rs. 10.3 less than as result of 100 Rs. increase in Other PSL as compare to public sector banks. In absolute terms in case of private banks as a result of 100 Rs. increases in Other PSL the net increase in NPA is equal to (20.3-10.3) 10 Finally it can be concluded that private sector banks are more efficient in managing NPA in relation with Other PSL.

\section{Findings:}

- The impact of PSL on NPA is shown below in Table 15. This indicates with increase of 100 Rs. of PSL, NPAs of banks increase with 8.2 paise. This effect is different for different sectors of PSL. If we see the different sectors of PSL, Other PSL is increasing the NPA more than the other categories. With increase of 100 Rs of Agriculture PSL, NPAs of bank increase with 19.3 paise, similarly with increase of 100 Rs of SSI PSL, NPAs of bank increase with 22.9 paise, and with increase of 100 Rs of Other PSL, NPAs of bank increase with 33.1 paise 


\begin{tabular}{|l|l|}
\hline Table 15: Impact of PSL on NPA sector wise \\
\hline PSL and different Sector of PSL & $\beta$ coefficient with NPA \\
\hline PSL & 0.082 \\
\hline Agriculture PSL & 0.193 \\
\hline SSI PSL & 0.229 \\
\hline Other PSL & 0.331 \\
\hline
\end{tabular}

- The impact of PSL and its different sectors on NPA is different for public and private sector banks. The F test and Hausman test tell that intercept and $\beta$ coefficient with NPA of public and private banks is different. Means impact of PSL of pubic banks on NPA is different from private banks.

- Comparison of intercept and $\beta$ coefficient of public banks and private banks is being done in table 16. It is clear from table 16 that PSL intercept of public banks is 27710.06 and private banks intercepts is 18152.12 less than public banks and $\beta$ coefficient of public banks of PSL is 0.0636 and private banks PSL $\beta$ coefficient is .025 less than public banks. It can be stated that if NPA of public banks increase with 6.36 paise with 100 Rs increase of PSL than NPA of private banks increase with 3.86 paise(6.36-2.5).

\begin{tabular}{|c|c|c|c|c|}
\hline \multicolumn{5}{|c|}{$\begin{array}{l}\text { Table 16: Comparison of Intercept and } \beta \text { Coefficient of Public Banks and Private } \\
\text { Banks }\end{array}$} \\
\hline $\begin{array}{lr}\text { PSL } & \text { and } \\
\text { different } & \text { Sector } \\
\text { of PSL } & \end{array}$ & $\begin{array}{l}\text { Intercept } \\
\text { of public } \\
\text { banks }\end{array}$ & $\begin{array}{l}\text { Intercept } \\
\text { of private } \\
\text { banks as } \\
\text { compare to } \\
\text { public } \\
\text { banks }\end{array}$ & $\begin{array}{l}\beta \text { coefficient of } \\
\text { public banks }\end{array}$ & $\begin{array}{ll}\beta \text { coefficient of } \\
\text { private banks as } \\
\text { compare } & \text { to } \\
\text { public banks } & \end{array}$ \\
\hline PSL & 27710.06 & -18152.12 & 0.0636 & -0.025 \\
\hline Agriculture PSL & 28177.46 & -20314.47 & 0.1471 & -0.0447 \\
\hline SSI PSL & 30466.05 & -21259.86 & 0.182 & -0.0930 \\
\hline Other PSL & 28216.33 & -20093.44 & 0.203 & -0.103 \\
\hline
\end{tabular}

If we see the different sectors of PSL private banks NPAs are less affected because of PSL in comparison of public banks. Due to 100 rupees increase of Agriculture PSL public banks NPAs increase with 14.71 paise while private banks NPAs increase with 10.24 (14.71-4.47) paise. Due to 100 rupees increase of SSI PSL public banks NPAs increase with 18.2 paise while private banks NPAs increase with 8.9 (18.2-9.30) paise. Due to 100 rupees increase of Other PSL public banks NPAs increase with 20.3 paise while private banks NPAs increase with 10 (20.3-10.3) paise.

\section{CONCLUSION:}

Priority Sector Lending is having a significant impact on NPA in case of both public banks and private banks, but public banks NPA is more affected by PSL as compare to private banks. In case of public banks out of subsectors of PSL; SSI and Other PSLs is major contributor to NPA. In case of private banks out of subsectors of PSL; Agriculture and Other PSL is equally contributing to the NPA. 


\section{AbBreviations:}

PSL: Priority Sector Lending

NPA: Non Performing Asset

RBI: Reserve Bank of India

ANBC: Actual Net Banking Credit

SSI: Small Scale Industries

\section{LIST OF TABLES:}

\begin{tabular}{|c|c|}
\hline Table No. & Title \\
\hline 1 & Targets for Domestic Commercial Banks \\
\hline 2 & Total NPA and PSL of Public and Private Banks \\
\hline 3 & Pooled Regression between Total NPA and PSL \\
\hline 4 & Panel Regression Model of Total NPA and PSL \\
\hline 5 & Two Way Fixed Effect Panel Regression Model of Total NPA and PSL \\
\hline 6 & Pooled Regression between Total NPA and Agriculture PSL \\
\hline 7 & Panel Regression between Total NPA and Agriculture PSL \\
\hline 8 & Two Way Fixed Effect Panel Regression between Total NPA and Agriculture PSL \\
\hline 9 & Pooled Regression between Total NPA and SSI PSL \\
\hline 10 & Panel Regression between Total NPA and SSI PSL \\
\hline 11 & Two Way Fixed Effect Panel Regression between Total NPA and SSI PSL \\
\hline 12 & Pooled Regression between Total NPA and Other PSL \\
\hline 13 & Panel Regression between Total NPA and Other PSL \\
\hline 14 & Two Way Fixed Effect Panel Regression between Total NPA and Other PSL \\
\hline 15 & Impact of PSL on NPA sector wise \\
\hline 16 & Comparison of Intercept and $\beta$ Coefficient of Public Banks and Private Banks \\
\hline
\end{tabular}

\section{REFERENCES:}

1. Ahmed, U. D. (2010). Priority Sector Lending By Commercial Banks in India: A Case of Barak Valley. Asian Journal of Finance \& Accounting, 2(1).

2. Patidar, S., \& Kataria, A. (2012). Analysis of NPA in priority sector lending: A comparative study between public sectorbanks and Private sector banks of India. Bauddhik, 3(1), 54-69.

3. Uppal, R. K. (2009). Priority sector advances: Trends, issues and strategies. journal of Accounting and Taxation, 1(5), 079-089. 
4. Raman, P., \& Thangavel, N. SOCIAL BANKING IN INDIA: PRIORITY SECTOR LENDING AND ITS DEVELOPMENTS-A STUDY.

5. Reddy, P. K. (2002). A comparative study of Non Performing Assets in India in the Global context-similarities and dissimilarities, remedial measures. Retrieved on March, 23, 2012.

6. Mehta, L., \& Malhotra, M. (2014). Empirical Analysis of Non Performing Assets Related to Private Banks of India. International Journal of Management Excellence, 3(1), 386-391.

7. Patel, S. G. (1996). Role of Commercial Banks' Lending to Priority Sector in Gujarat-An Evaluation. Finance India, X (2), 389-393.

8. Shabbir, N., \& Mujoo, R. (2014). Problem of Non Performing Assets in Priority Sector Advances in India. Journal of Economics, 2(1), 241-275.

9. Veerakumar, K. (2012). Non-performing assets in priority sector: A threat to Indian scheduled commercial banks. International Research Journal of Finance and Economics, (93).

10. Vallabh, G., Bhatia, A., \& Mishra, S. (2007). Non-Performing Assets of Indian Public, Private and Foreign Sector Banks: An Empirical Assessment. The IUP Journal of Bank Management, 6(3), 728.

11. Chaudhary, K., \& Sharma, M. (2011). Performance of Indian public sector banks and private sector banks: A comparative study. International journal of innovation, management and technology, 2(3), 249-256.

12. Ghosh, S. (2011, June). Management Of Non-Performing Assets In Public Sector Banks: Evidence From India. In International Conference on Management (ICM 2011) Proceeding (No. 2011-057-173). Conference Master Resources.

13. Aggarwal, S., \& Mittal, P. (2012). Non-Performing Assest: Comparative Position of Public and Private Sector Banks in India. International Journal of Business and Management Tomorrow, 2(1), 1-7.

14. Report of Trend and Progress of Banking in India, Reserve Bank of India (from 2000 to 2013)

15. Reserve Bank of India Annual Report (From 2000 to 2013)

16. Master Circular RBI/July/2013-13/108

17. Selvam N, Customer Perception on Reasons for Non Performing Assets, ASM's International EJournal of ongoing Research in Management, ISSN-2320-0065,2013

18. Nagarajan G, Non-Performing Assets is a Threat to India Bankng Sector -A Comparative study between Priority and Non-Priority Sector Leading in Public Sector Banks, International Journal of Advanced Research in Management and Social Sciences ISSN: 2278-6236, 2013 